\title{
Prostatic Urethra Cancer Pathologic Primary Tumor TNM Finding v8
}

National Cancer Institute

\section{Source}

National Cancer Institute. Prostatic Urethra Cancer Pathologic Primary Tumor TNM

Finding v8. NCI Thesaurus. Code C140446.

A pathologic finding about one or more characteristics of cancer in the prostatic urethra, following the rules of the TNM AJCC v8 classification system as they pertain to staging of the primary tumor. 